\title{
Bioeconomy as an innovative approach to rural development in the context of Common Agricultural Policy in EU
}

\author{
Teodorina Turlakova ${ }^{1 *}$ \\ ${ }^{1}$ Department of Agricultural Economics, Faculty of Economics, University of Economics, Varna, \\ Bulgaria
}

\begin{abstract}
Bioeconomy is an innovative approach in the economy of the region, aimed at integrating the available natural and labour resources, production facilities, the achievements of science in the field of innovation technologies. These are related to the production of material goods, the conversion of production and energy in the direction of fuller utilization of organic and mineral sources as a raw material resource for achieving sustainable development in the field of production and consumption, stable economic development and growth living standards of the population while protecting the environment and resources. The aim of the report is to analyze the possibilities for applying the bioeconomy in rural areas through research and innovation, stimulating private investment, developing new value chains and engaging stakeholders. The role of the CAP in supporting and financing activities of the bio and circular economy models is argued.
\end{abstract}

\section{Introduction}

Agriculture and forestry are an integral part of the rural economy. They provide the basis for food, feed and non-food products to meet the needs of consumers and a wide range of industries developing in the area. About $70 \%$ of the EU's land area is covered by forests or agricultural land, which is why primary production activities have a huge impact on the integrity of rural areas in terms of preserving natural capital, quality of life and job creation.

The growing world population together with economic growth and changing consumption patterns further increase the demand for primary products. This leads to pressure to increase agricultural productivity, which is accompanied by declining natural resources and the effects of an increasingly changing climate. Coordinating production with the sustainable management of land and other natural resources is considered a major challenge for current and future agricultural and forestry systems. Research and innovation are crucial to support the transition to more sustainable, "triple-efficient" types of primary production, covering economic, social and environmental goals. As the European Commission notes, "We live in a world of limited resources. Global challenges such as climate change, land degradation and ecosystems, combined with growing demand for food, feed and energy, are forcing us to look

\footnotetext{
*Corresponding author: tturlakova@ue-varna.bg
} 
for new ways to produce and consume. A sustainable and circular bioeconomy contributes to addressing these challenges" [1].

\section{The concept of bioeconomy - characteristics, goals and objectives}

Bioeconomy is thought to be closely linked to the early development of theories of fishing economies, mainly in the mid-1950s by Canadian economist Scott Gordon [9]. The authors base their ideas on the achievements of the time in biological fishing modelling. In support of their thesis are the works of M. B. Schaefer [15], who establishes relationships between fishing activities and biological growth through mathematical modelling. Empirical research confirms the link between economics and ecology, the environment and resource protection.

The terms "bioeconomy" or "bio-based economy" were used in the first years of the 21 st century [13], and a few years later bioeconomy entered the political discussions in the European sphere [4].

However, the theory of the bioeconomy stems from earlier strategic programs of the European Commission (EC), including the 1993 White Paper, which emphasizes the need for non-physical investment based on knowledge and the role of biotechnology in innovation and growth [2]. The 2000 Lisbon Agenda requires global leadership in the knowledge-based economy to ensure competitiveness and economic growth [5].

The conference in 2007 outlined the prospects for the European bioeconomy over the next 20 years [8] to establish:

- know ledge-based bioeconomy in European political circles;

- the bioeconomy as a key component for smart and green growth [3].

According to modern economic views, "the bioeconomy can be defined as an economy in which the basic building blocks for materials, chemicals and energy are obtained from renewable biological resources" [14].

The main goal of the bioeconomy is the maximum utilization of all organic and mineral raw materials obtained from agricultural production, forestry, fish farming, aquaculture, industry. Through the achievements of innovative biotechnologies and nanotechnologies their transformation into by-products for final consumption. and energy, achieving a full cycle of substances and increasing energy independence from depletable energy sources at the expense of inexhaustible ones.

An important role in achieving the mission and goals of the bioeconomy is played by the active involvement of science and the application of innovative achievements in the processes of production and transformation of production, the use of biotechnologies related to the participation of microorganisms, the achievements of genetics for productivity, adaptability of plants and animals in the agricultural sector, nutrigenetics and nutrigenomics, the intersection between genes, nutrition and health, improving the quality and nutritional value of products and diversifying the range of products, the introduction of specific regional, branded and boutique products.

From the point of view of rural development, the bioeconomy is an innovative approach to solving the problems of the population by integrating the available natural and labor resources, production capacities, the achievements of science in the field of innovative technologies related to the production of material goods. energy, for fuller utilization of organic and mineral sources as a raw material resource for achieving sustainable development in the field of production and consumption, stable economic development and raising the living standard of the population while protecting the environment and resources. 


\section{The bioeconomy as an element of the EU's Common Agricultural Policy (CAP)}

Today's European bioeconomy encompasses agriculture, forestry and fisheries, the food sector, bioenergy and the organic products sector. It generates an annual turnover of 2.3 trillion euros and provides employment to about 18 million people. It is estimated that organic products-based sectors could create up to one million green jobs by 2030, especially in rural and coastal areas [11]. These figures not only emphasize the importance of the existing bioeconomy for the European economy and society, but also point to opportunities for better integration of activities from different sectors and expansion of the production of bio-based products. Europe is considered a world leader and pioneer in a number of areas of life sciences and related technologies. However, the United States and some Asian countries, such as China, are investing heavily in the bioeconomy. One such indication is the National Bioeconomy - a US Plan [17] published in 2012 to strengthen its work on the bioeconomy and bio-based products. Because Europe is believed to be lagging behind these countries in market development [16].

The European Agricultural Fund for Rural Development (EAFRD) supports a wide range of rural bioeconomy projects as well as awareness-raising activities to provide key investments to enable the transformation of the bioeconomy in rural areas.

The bioeconomy is part of the nine objectives of the CAP. The main documents supporting the bioeconomy are:

- Europe 2020 Strategy - the goal is to develop the bioeconomy as a key element for smart and green growth in Europe.

- Strategy "Innovation for Sustainable Growth: A Bioeconomy for Europe". In 2012, the first bioeconomy strategy was presented. The aim is to use resources sparingly, sustainably using renewable resources for industrial purposes and environmental protection.

In 2018, the European Commission updates the strategy for the bioeconomy "Sustainable Bioeconomy for Europe: strengthening the link between the economy, society and the environment." The aim is to strengthen the development of a sustainable European bioeconomy in order to correspond as well as possible with the UN Program and the Paris Agreement on Climate Change. The EU's Bioeconomy Strategy 2018 defines the bioeconomy as "those parts of the economy that use renewable biological resources from land and sea, such as crops, forests, fish, animals and micro-organisms, to produce food, materials and energy."[6]

- The Horizon 2020 Research and Innovation Program supports the rural bioeconomy.

- RDP 2014-2020 direction "Food security, sustainable agriculture and forestry, marine and inland water research and bioeconomy".

The RDP 2014-2020 plays an important role in the introduction of the circular economy model. It has an impact on the conservation of biodiversity, resource efficiency, sustainable use of natural resources, adaptation of economic activity to climate change. The Program aims to achieve cross-sector objectives related to the bioeconomy, innovation in agricultural and non-agricultural activities and achieving sustainability in rural development.

Some of the measures in the RDP 2014-2020 support the preservation of water quality, protection of natural landscapes and rare breeds of animals and plant varieties, protection of important habitats and biodiversity in lands of high natural value, promotes sustainable land management, undertake various measures to preserve carbon stocks in the soil and act in the direction of preventing soil erosion and floods, stimulate the development of organic farming.

Priority areas set out in the RDP 2014-2020 and related to the circular economy are:

Priority 1 - Stimulating innovation, cooperation and knowledge base development in rural areas; Strengthen the links between agriculture, food production, forestry and research 
and innovation, including with a view to improving environmental governance and environmental performance.

Priority 4 - Restoration, protection and strengthening of biological diversity; Improving water management; Prevent soil erosion and improve their management.

Priority 5 - Increasing the efficiency of water consumption in agriculture; Increasing the efficiency of energy consumption in agriculture and the food industry; Facilitating the supply and use of renewable energy sources, by-products, waste and residues, and other non-food raw materials for the purposes of the bioeconomy; Reduction of greenhouse gas and ammonia emissions from agriculture; Stimulating carbon storage and absorption in the agriculture and forestry sector.

According to the future Common Agricultural Policy, the European Commission will not approve a Member State's national strategic plan that does not include the promotion of the bioeconomy in agriculture.

Through the national strategic plans set out in the proposals for the new CAP, all Member States will outline how they want to achieve these 9 objectives, including the promotion of the bioeconomy, using CAP instruments.

EU member states will have more freedom under the EC's proposal for the future CAP, which will allow them to focus on their bioeconomy and respond to the higher ambitions of future environmental and climate change policy.

Food production and agriculture are the dominant segments of the bioeconomy in terms of employment, turnover and value added. Food and agriculture systems are a key part of the bioeconomy, but they urgently need to be transformed to become more resilient, more sensitive to food, stable and inclusive [12].

A sustainable bioeconomy can turn biowaste, residues and discarded raw materials into valuable resources and create innovations and incentives to help retailers and consumers reduce food waste by $50 \%$ by 2030 [7].

Some of the main activities related to the bioeconomy are the production of biomass, biogas, manure, biodiesel.

The production of basic biomass in agriculture in the country in 2019 amounts to 15.1 million tons, which is 2.6 times more than in 2007. The highest growth is in industrial crops, and the largest volume is biomass from cereals.

In the production of biogas, various raw materials of agricultural origin are used - silage corn, manure, grass silage, livestock waste, etc. $40 \%$ of the production of biogas from agricultural substrates is obtained from silage corn. In 2019185.6 thousand tons were used, i.e. nearly 87 thousand decares are intended to serve the production of biogas from the harvested 299.3 thousand decares. On the other hand, 277,000 dairy cows need 1,260,000 tons of silage, which requires 590,000 decares, or twice as much as the harvested ones. Therefore, the shortage is 291 thousand decares, without silage corn being used for biogas production, and when using it - 378 thousand decares.

Manure is increasingly used for on-site biogas production on farms. It is only one of the substrates involved in the production process. There is no data on the amount used to produce biogas, but indicative estimates can be made. Assuming that biogas from anaerobic substrates is produced from agricultural raw materials and that $40 \%$ of the produced biogas is from manure, as it is only one of the substrates, $18.2 \mathrm{t}$.

Biodiesel is produced mainly from rapeseed and sunflower and belongs to the category of "first generation biodiesel". Produced from organic waste (used animal and vegetable oils and food waste) is second generation biodiesel. According to the Law on Energy from Renewable Energy Sources, the biological component in diesel fuel should be $6 \%$, of which $5 \%$ biodiesel first generation and $1 \%$ - second generation. In 2018, the mandatory use of second-generation biodiesel was introduced, but no significant change is expected in the amount of energy crop production, which significantly exceeds the amount that is processed 
in the country into biodiesel. Sunflower exports are mainly to the Netherlands and Germany, and the rapeseed exports to Belgium, Germany and France.

The agriculture and forestry sectors have been creating value in the European economy for several generations. Now, in addition to their traditional roles, farmers and foresters are at the heart of the European bioeconomy. The goal of moving towards a carbon-neutral society, in line with the European Commission's long-term strategy for 2050 "Clean Planet for All"[10], as well as the EU's Bioeconomy Strategy, involves replacing petroleum and non-renewable materials with biological ones. This includes the conversion of organic waste, agricultural and forestry residues and industrial processes, and food waste into valuable and safe bio-based products to meet the goals of the circular economy.

\section{Conclusion}

The development of the bioeconomy is an opportunity to find solutions to societal challenges in rural areas related to ensuring food security; expanding information on the bioeconomy and strengthening the dialogue between society and bioeconomy stakeholders; reducing dependence on non-renewable resources; limiting climate change, protecting biodiversity and natural resources; stimulating employment, economic growth and competitiveness; full participation of the agricultural sector in building an innovative economy that combines the pursuit of food security and sustainable development of the sector with the use of renewable biological resources for industrial and energy purposes, ensuring biodiversity and environmental protection. This vision is fully compatible with the strategy for the development of the bioeconomy as a means of achieving sustainable rural development, opening new market niches, improving the organization of production processes and sales of organic products, creating clusters involving all participants in the conversion chain of raw materials in products, increasing gross value added and increasing its competitiveness.

\section{References}

1. Bioeconomy Factsheet, European Commission, 2018, https://ec.europa.eu/research/bioeconomy/pdf/ec_bioeconomy_actions_2018.pdf\#view $=$ fit\&pagemode $=$ none

2. European Commission (EC), Growth, Competitiveness, Employment: The Challenges and Ways forward into the 21st Century, White Paper, COM (93)700; (European Commission: Brussels, Belgium, 1993)

3. European Commission (EC), Innovating for Sustainable Growth: A Bioeconomy for Europe; COM (2012) final, (European Commission: Brussels, Belgium, 2012)

4. European Commission (EC), Staff Working Document on Innovating for Sustainable Growth: A Bioeconomy for Europe, SWD (2012) final, (European Commission: Brussels, Belgium, 2012)

5. European Commission (EC), The Lisbon European Council: An Agenda of Economic and Social Renewal for Europe, (European Commission: Brussels, Belgium, 2000)

6. European Commission, DG Research and Innovation, https://ec.europa.eu/research/bioeconomy/index.cfm?pg=policy

7. Food 2030, https://ec.europa.eu/research/bioeconomy/index. cfm?pg=policy\&lib=food 2030

8. German Presidency, En Route to the Knowledge-Based Bio-Economy; German Presidency of the Council of the European Union: Cologne, Germany (2007) 
9. G. H. Scott (1954), J. Polit. Econ., 62(2), 124 - 142 (1954)

10. European Commission, 2050 long-term strategy, https://ec.europa.eu/clima/policies/strategies/2050_en

11. European Commission, Bioeconomy actions, https://ec.europa.eu/research/bioeconomy/pdf/ec_bioeconomy_actions_2018.pdf\#view $=$ fit\&pagemode $=$ none

12. https://enrd.ec.europa.eu/sites/default/files/enrd_publications/publi-eafrd-brochure-09bg_2021.pdf

13. B. Kamm,M. Kamm, Appl. Microbiol. Biot, 64, 137-145 (2004)

14. K. McCormick, N. Kautto, Sustainability, MDPI J., 5(6), 2589-2608 (2013)

15. M. B. Schaefer, J Fish Res Board Can, 14, 683-686 (1957)

16. M. Kardung, K. Cingiz, O. Costenoble, R. Delahaye, W. Heijman, M. Lovrić, M. van Leeuwen, R. M'Barek, H. van Meijl, S. Piotrowski, T. Ronzon, Johanne, Sustainability, MDPI J., 13(1), 1-24 (2021)

17. White House, National Bioeconomy Blueprint, (White House: Washington, DC, USA, 2012) 